\title{
Social Identities in the Field How Fluctuating Fieldworker Identities Shape Our Research
}

\author{
Gosovic, Anna Kirkebæk Johansson
}

Document Version

Accepted author manuscript

Published in:

Journal of Organizational Ethnography

DOI:

10.1108/JOE-12-2017-0069

Publication date:

2018

License

Unspecified

Citation for published version (APA):

Gosovic, A. K. J. (2018). Social Identities in the Field: How Fluctuating Fieldworker Identities Shape Our

Research. Journal of Organizational Ethnography, 7(2), 186-198. https://doi.org/10.1108/JOE-12-2017-0069

Link to publication in CBS Research Portal

\section{General rights}

Copyright and moral rights for the publications made accessible in the public portal are retained by the authors and/or other copyright owners and it is a condition of accessing publications that users recognise and abide by the legal requirements associated with these rights.

Take down policy

If you believe that this document breaches copyright please contact us (research.lib@cbs.dk) providing details, and we will remove access to the work immediately and investigate your claim. 


\title{
Social Identities in the Field: How Fluctuating Fieldworker Identities Shape Our Research
}

\author{
Anna Kirkebæk Johansson Gosovic
}

Journal article (Accepted manuscript*)

\section{Please cite this article as:}

Gosovic, A. K. J. (2018). Social Identities in the Field: How Fluctuating Fieldworker Identities Shape Our

Research. Journal of Organizational Ethnography, 7(2), 186-198. 00I: 10.1108/J0E-12-2017-0069

\section{DOI: 10.1108/J0E-12-2017-0069}

This article is () Emerald Group Publishing and permission has been granted for this version to appear here: https://research.cbs.dk/da/publications/social-identities-in-the-field-how-fluctuating-fieldworker-identi. Emerald does not grant permission for this article to be further copied/distributed or hosted elsewhere without the express permission from Emerald Group Publishing Limited.

* This version of the article has been accepted for publication and undergone full peer review but has not been through the copyediting, typesetting, pagination and proofreading process, which may lead to differences between this version and the publisher's final version AKA Version of Record. 


\section{Social identities in the field: How fluctuating fieldworker identities shape our research}

\section{Introduction}

By its very definition, organizational ethnography takes place within organizations; most often formal organizations whose layout and structure are guided by familiar managerial norms. Scholars have paid attention to various methodological aspects of fieldwork in such familiar settings, and have focused on e.g. "insider research" (Brannick and Coghlan, 2007, pp. 59-60) and "at-home ethnography" (Alvesson, 2009, pp. 159-160). However, such categorizations of being either athome or away and having an identity as either an insider or an outsider entail an assumption that we work from only one position when conducting our fieldwork and that this position can be determined a priori. The purpose of this article is to contribute to developing our understanding and practice of fieldwork in familiar settings by expanding the literature on fieldworker identities (See e.g. Cunliffe and Karunanayake, 2013; Ergun and Erdemir 2010; Järventie-Thesleff et al., 2016; Kusow, 2003). Building on previous literature within organizational ethnography, this article introduces a reflexive framework for understanding the multiple and fluid identities that we purposefully take on, accidentally acquire, unintentionally are ascribed with and experience during ethnographic fieldwork in familiar settings. It further reflects on the ways in which these identities shape our data generation and interpretation process.

Organizations today are increasingly globalizing and operating across countries and cultures, which forces ethnographers to consider studying multiple field sites rather than staying in one location (Marcus, 1995; Smets et al., 2014). Given the dispersed nature of global organizations, when conducting ethnographic fieldwork, we will rarely be either insider or outsider within the entirety of such (cf. Marschan-Piekkari et al., 2004). By expanding the literature on fieldworker identities, this 
article develops a critique of the spatial and temporal notions often attached to fieldwork in familiar settings by demonstrating how outsider identities are ascribed even "at-home" and how insider identities can be experienced when away. Rather than conceptualizing the identity of the researcher and the nature of the fieldwork in spatial and temporal terms, this article proposes to conceptualize "insider" and "outsider" as ascribed, changing and sometimes volatile social identities. The term ethnography in familiar settings is applied to refer to the variety of research strategies employed to study the familiar, such as "insider" or "at-home" ethnography.

Within organizational ethnography, only limited attention has been paid to the simultaneous processes of both insider and outsider identity creation that takes place throughout a fieldwork and the opportunities and limits these identities set for the data we get access to generate. Some work has been done on fieldworker identities, which depicts the fluid nature of these (see e.g. JärventieThesleff et al., 2016). However, such studies focus primarily on the identity shifts experienced by researchers when having one foot in academia and another in the context under study and less on the identities we acquire within the field and the impact of such identities on our research findings. Based on ethnographic studies in a multinational biopharmaceutical corporation, this article sets out to explore the following research question:

- How are fieldworker identities created, changed, and interrupted during the course of an ethnographic research in a familiar setting?

The insights and arguments presented in this article may inform ethnographers engaged in various research approaches in familiar settings. However, because of the intraorganizational heterogeneity and local organizational identities often found in multinational companies (MNCs) (Cf. Pant and Ramachandran, 2017; Roth and Kostova, 2003) and the complex landscape of possible fieldworker 
identities that are consequently available, insights from this article are particularly relevant for organizational ethnographers studying within MNCs. Especially since subsidiaries' locations may carry with them assumptions about fieldworker identities as either insiders or outsiders, and because the identities we are ascribed (and the challenges they bring) may vary across business units (Cf. Marschan-Piekkari et al., 2004).

This article is structured as follows. First, I present an outline of how organizational ethnography in familiar settings has been conceptualized within previous research and highlight that within this literature, there is an assumption that the familiarity or strangeness of a field can be determined a priori. Then, I highlight previous studies on identity within organizational ethnography and point out that nuances described in these studies have not been utilized sufficiently for methodological reflections about our own identities as fieldworkers in familiar fields. Next, I introduce a theoretical frame for understanding identities as social processes (Jenkins 2008) and argue for its usefulness in bringing forth new perspectives on how such fluid fieldworker identities shape our data generation and analytical processes. Within this framework, I then present findings from an ethnographic study within an MNC and discuss the implications, contributions and limits of these findings.

\section{Theory}

\section{Organizational ethnography in familiar settings: Central conceptualizations}

Within traditional teachings of anthropology, the (Western) fieldworker was assumed to be very different from the (non-Western) other and thus was warned of the "culture shock" she would encounter when arriving at her field site "away" from home (DeWalt and DeWalt, 2002, pp. 6569). Gradually, however, she would familiarize herself with the otherness encountered and slowly work her way from being an outsider to becoming an insider. Later, organizational ethnography 
emerged, and researchers now often conduct their fieldwork in familiar contexts. Some of the most widely discussed methodological conceptualizations of such research are at-home ethnography (Alvesson, 2009), membership research (Adler and Adler, 1987), and the distinction between insider and outsider ethnography (Brannick and Coghlan, 2007).

In 1987, Adler and Adler (1987) reflected on different membership roles in field research as positions from which a researcher can conduct participant observation. Adler and Adler distinguish between three membership roles, central to which are their insider affiliations. The most involved is the "complete membership role", where the researcher studies her topic from the perspective of full members by either studying groups in which she has prior membership or becoming a member of these groups (Adler and Adler, 1987, p. 35). In his widely known writings on "at-home ethnography", Alvesson (2009, pp. 159-160) describes the spatial notion inherent in original teachings of ethnography, where the fieldworker is assumed to commence her research at a distance and slowly move closer to the lived realities of the people under study. Instead, he proposes an ethnography where we start close up and study our own setting rather than the setting of the other. Alvesson first terms this "self-ethnography" (Alvesson, 2003, pp. 174-178) but later uses the more well-known term "at-home ethnography" (Alvesson, 2009, pp. 159). At-home ethnography, he writes, is research carried out in a setting to which the researcher has "'natural access' and in which s/he is an active participant, more or less on equal terms with other participants” (Alvesson, 2009, p. 159). An example is a researcher exploring her own university context. In at-home ethnography, however, the primary focus of the researcher is not the research itself but rather the "natural" role she has in the context under study. At-home ethnography thus aims "to utilize the position one is in for another, secondary purpose, that is, doing research on the setting of which one is a part" (Alvesson, 2009, p. 160). Further, in Alvesson's definition of at-home ethnography, research is an 
opportunistic and almost accidental endeavor taken up by the researcher-participant whenever the opportunity arises. As opposed to more conventional ethnography, where the struggle of the ethnographer is to "break in" to an unknown cultural world, the challenge involved in at-home ethnography is, according to Alvesson, to "break out" from the taken-for-grantedness of a familiar setting (Alvesson, 2009, p. 162). Building on Alvesson's first publication about at-home ethnography and Adler and Adler's definition of complete membership role, Brannick and Coghlan introduce the idea of "insider research" (2007, pp. 59-60). However, in contrast to Alvesson, they write that when a scholar is engaged in insider research, the research task is formal and planned rather than accidental. Insider researchers are, however, still native to the setting under study, and the authors similarly address the risk of failing to notice important aspects of the field because of its familiarity (Brannick and Coghlan, 2007). Thus, regardless of the terminology, we are often warned about the pitfalls of failing to notice the particularities of our own community (Delamont, 2007; Ginkel, 1998; See also Ybema and Kamsteeg, 2009).

With a similar concern, in 1995, Van Maanen pleaded that researchers studying at home should engage in what he called "defamiliarization", and he famously argued that ethnographers should focus on "making the familiar strange" when studying their own context (Van Maanen, 1995, p. 20). This comment has had particular resonance within the organizational studies community, for whom organizations are rarely unfamiliar. Ybema and Kamsteeg (2009) followed up on this point in their plea for ethnographers to refocus on the exercise of creating distance between themselves and the field. They write, "For organizational ethnographers, the very 'un-strangeness' of the surroundings in their research prevents them from seeing it" (Ybema and Kamsteeg, 2009, p. 102). But are organizations always "un-strange" just because the concept of an organization is familiar or because our position in it is equal to that of our informants? This article will challenge this familiarity assumption often attached to fieldwork in familiar settings. 


\section{Insiders or outsiders: Fieldworker identities in organizational ethnography}

Within organizational ethnography, identity is a broad and well researched field of inquiry (See e.g. Alvesson et al., 2008), and several contributions have established the changeable nature of identities (See e.g. Alvesson, 2010; Beech, 2011; Brown, 2015; Ellis and Ybema, 2010). Yet, when it comes to considerations of ethnographers' own researcher identities, the field of research seems less developed. Important nuances about the instability of identities seem to have not been incorporated sufficiently into our methodological reflections, and many scholars within organizational ethnography have described the researcher's identity as an either/or position (Karra and Phillips, 2008). Others have described it as a gradual move from being an outsider to becoming an insider, and vice versa when the research is being conducted in familiar settings (see e.g. Alvesson, 2009; Ybema and Kamsteeg, 2009). However, the position taken in this article is that the ethnographer's identity in the field cannot be determined a priori as either insider or outsider (cf. Ergun and Erdemir, 2010; Kusow, 2003; Narayan, 1993). Outside of organizational ethnography, this problematization of the insider-outsider dichotomy is far from a new (See e.g. Merton, 1972), and within various ethnographic research fields it has long been demonstrated how social markers such as age, race, nationality and gender influence the position and access of the fieldworker - even when she is "at home" (See e.g. Bell, 1999; Bolak, 1996; Cui, 2015; Ergun and Erdemir, 2010; Gurney, 1985; Halstead, 2007).

A few recent contributions within organizational ethnography have challenged the insider-outsider dichotomy and the temporal continuum on which our fieldworker identities are assumed to move. A reflexive approach is central to these writings. One recent and noteworthy contribution by JärventieThesleff et al (2016) describes how professional identities and identity work play out in at-home 
ethnography. Drawing on earlier comments about the taboo of telling one's own stories (Anteby, 2013), the authors emphasize the importance of legitimizing an open reflection about our identities in the field, particularly when conducting at-home ethnography (Järventie-Thesleff et al., 2016). Based on two at-home ethnographic $\mathrm{PhD}$ projects, the authors demonstrate the various identity processes through which ethnographers move during the course of their studies. Although a temporal description of how ethnographers move from practitioner identities to academic identities runs through the article, the authors demonstrate that non-linear shifts back and forth between identities break this temporal progression (Järventie-Thesleff et al., 2016; see also Cunliffe and Karunanayake, 2013; Winkler, 2012). The authors focus on the experienced identity shifts of the athome ethnographer between belonging to academia and to the field, whereas this article will focus on the identity processes within the field and the impact of such processes on our research. Thus, building on the work by Järventie-Thesleff et al. and its important focus on reflexivity and fluidity in fieldworker identity creation, this article proposes a theoretical framework that attempts to capture the space and tension between externally defined and self-experienced fieldworker identities.

\section{Social identities: A processual concept}

In his book Social Identity, first published in 1996, anthropologist Richard Jenkins (2008) provides a detailed account of identity creation and of the classification of the self and others. As implied in the book title, Jenkins views identity as a social and relational construct, and he prefers to refer to identification rather than identity to emphasize the processual view within the concept. To understand identification, Jenkins introduces three distinct and interacting orders: the Institutional Order, the Interaction Order and the Individual Order. The aim of Jenkins' argument is to address what he perceives as a false distinction between structure and action within the structuration debate 
at the time. Within the same vein, it must be noted that Jenkins' orders of identification always overlap and interact in the process of identification. Thus, whereas other scholars distinguish between individual identities and social identities (Brown, 2015), for Jenkins, all orders of identification are social.

The Institutional Order refers to the processes by which a group identifies as a group within itself and the process by which a group is categorized as a group by others. This aspect of identity creation is, as will be shown, central to organizational ethnography, as organizations are also legal entities and the formal categorizations as insider or outsider can either provide or prohibit access to certain information and experiences. The Interaction Order is highly influenced by Goffman's (1990) work on impression management and front-stage and back-stage identities. It refers to the ways in which our active attempts to take on an identity externally depend on the acceptance of this identity by others. This aspect of identity creation is particularly central for our access in the field as organizational ethnographers and will be employed to demonstrate how the data we generate is shaped by our success or failure with taking on a particular identity. The Individual Order refers to the notion of selfhood and how this is co-constructed in a synthesis between how we as individuals experience and define ourselves and how the external world defines us. Jenkins views selfhood as a person's embodied experience of identity, as our sense of self is always braided into past experiences and feelings. For organizational ethnographers in familiar fields, this aspect of identity creation is particularly central, as embodied experiences of belonging and familiarity may affect our notions of selfhood and hereby our data. Thus, as will be elaborated later, our data generation, what we write and who we write about may be influenced by the attachments we feel to the field and the social bonds we create. Jenkins' concept of social identities emphasizes individual agency in identity creation while still considering the impact of others' definitions of us. Drawing on Jenkins' orders of identification, this article demonstrates how identities are created at the intersection 
between researcher selves and ascriptions from the field. I use these insights to reflect upon how the multiple fieldworker identities we shift between guide and limit our ethnographic studies.

\section{Methodology and empirical context}

The empirical material laying the basis for this article was generated in 2017 within a multinational biopharmaceutical company. The research was conducted under a funding scheme where I, as a $\mathrm{PhD}$ scholar, was jointly financed by this company and by a Danish government fund. Within this scheme, the researcher is hired, and partly paid, by a private company to do a $\mathrm{PhD}$ project on a topic deemed useful for this company. The researcher thus has a legal affiliation with the company by virtue of a job contract. The $\mathrm{PhD}$ project must have academic relevance and high scientific quality while still benefitting the company; thus, throughout the research, the researcher must balance this dual obligation. Hereby, despite the researcher's legal ties to the company, the research cannot be categorized as at-home ethnography in Alvesson's (2009) sense, as the research is an explicit purpose rather than an opportunistic occurrence. Moreover, I entered the company as a researcher and not as an employee transitioning into this role. Thus, the study cannot be described as insider research, as I did not occupy an insider position at the outset. It also cannot be categorized as fullmember research because by virtue of the split between my company membership and my research institution membership, I was a full member of neither.

The ethnographic study was designed following Brannen's (2011, pp. 131-132) definition of a "focal ethnography", which is an ethnography conducted using multiple data collection methods, documenting different perspectives on the phenomenon under study and the repetition of data collection over time. As recommended by Brannen (2011), this focal ethnography was followed up by comparative ethnographic case studies in selected countries in order to examine the strength and validity of the analyses. The overall focus of the $\mathrm{PhD}$ project is business ethics (See e.g. Ma et al., 
2012; Tseng et al., 2010), and the empirical point of inquiry is the company's ethics program (Kaptein, 2015), consisting of a code of ethics (Kaptein, 2004; Weaver, 1993) and various supporting training and awareness activities. I have been organizationally affiliated with the company's Ethics Department throughout the research.

\section{Findings}

Within this research project, the process of identification was ongoing, interlinked and often overlapping. For analytical clarity, however, the presentation of the findings is structured according to Jenkins' (2008) three orders of identification. By engaging with these three orders, I challenge the aforementioned temporal, spatial and a priori notions of insider and outsider, home and away and demonstrate how insider identities are ascribed even when away, how outsider identities are experienced in familiar fields and how insider moments occur for outsiders and vice versa. Below I describe these processes and use them to emphasize the impact of such fluid fieldworker identities on our research findings and interpretations.

\section{The Institutional Order: Categorized as an insider}

At the very beginning of the fieldwork, one of my primary ethnographic concerns was my organizational affiliation with the Ethics Department. Formally being an employee in the company and placed in the Ethics Department, I feared that I would be confused with an ethics "auditor", which might have inhibited the staff's and managers' willingness to participate in my research. Therefore, at first, I made an effort to emphasize my affiliation with the university, but I quickly realized the unfruitfulness of this effort, as people seemed reluctant to share information with me when I was seen as an outsider. In fact, against my expectations, I found it beneficial to clearly emphasize my employment with the company. Whenever I started asking questions, people seemed 
highly occupied with the terms of my contract. "So, you are an employee here?" or "Who do you report to in the company?" were common questions at the beginning of a conversation, asked in a wary tone. When I described the terms of my employment, however, the tone always lightened, and guards were lowered. In addition, I realized that in a business where patents and intellectual property have a significant presence, this reluctance to answer questions from outsiders is not surprising - particularly because a confidentiality clause is a standard requirement in every employee's job contract, and legal repercussions may apply to anyone who breaches it.

To understand why it was more helpful to assert an identity as an insider-employee than as an outsider-researcher, it is helpful to turn to Jenkins' Institutional Order. As Jenkins writes, the Institutional Order refers to the process by which identities are ascribed to organizational members based on the available classifications within the organization (Jenkins, 2008). Within the particular organizational context of the biopharmaceutical company and the reigning logics of non-disclosure, the two most immediate categories available were "employee" and "non-employee", or insider and outsider. Against my expectations, these categorizations determined the legal scope of the interaction between my research participants and me, and made it more fruitful for me to assert an identity as an insider-employee. However, as I will turn to next, on other occasions, though still within the insider frame, it was in fact fruitful to assert an identity as a researcher.

\section{The Interaction Order: Insider ascriptions and outsider moments}

Early in the fieldwork, I wanted to participate in one of the teams in charge of the clinical trials where new products are being tested on humans. I had assumed that this would be one of the more difficult forums to gain access to, but I met only open doors and helpful people, and I was immediately granted access to participate in two clinical trial project groups. When reflecting upon 
what I initially interpreted as sheer luck and reading my field notes, I realized that the reason I was given access to these clinical trials was my ascribed identity as a $\mathrm{PhD}$ fellow. The company in which I hold my $\mathrm{PhD}$ position is research-driven and highly specialized, and the number of $\mathrm{PhD}$ degree holders far exceeds the average in Danish companies. Thus, when I approached research and development managers and explained my position, they widely understood my need for data access despite our differences in subject matter specializations. Despite having only just entered the company, my self-ascription as a $\mathrm{PhD}$ fellow was successfully received, and my claims to data access were recognized as valid. Perhaps because of the familiarity with the concept of a PhD within the company, on this point, I was categorized as an insider - a more junior one, yes, but yet with a legitimate claim to what I was asking.

According to Jenkins, individuals negotiate their identity within a dialectic of identification that consists of internal and external moments. In the internal moment, individuals present an image of themselves for the acceptance of others, and in the external moment, others can either accept or reject it (Jenkins, 2008). In this case, the image I presented was accepted, which disrupted the outsider-to-insider continuum on which I would - according to spatial and temporal notions of the fieldwork experience - be assumed to gradually move. This is because, despite the novelty of the context, in the $\mathrm{PhD}$ dense environment of the biopharmaceutical company, my claim to an insider identity was accepted and acted upon.

On another occasion, much later in the fieldwork, I travelled to a subsidiary abroad with a colleague from the Ethics Department. I followed her there to observe and participate in a number of workshops for 40 local managers and some HR staff on the company's ethical principles. I knew that by virtue of my legal affiliation with the Ethics Department, I would risk being perceived as an authority, representing a corporate function, when arriving at the subsidiary (Cf. Marschan-Piekkari 
et al., 2004); thus, I decided to counteract this position and repeatedly mentioned my status as a student.

After the workshops for managers, my Ethics Department colleague trained local HR staff in how to conduct this workshop themselves, and I went through the training alongside the local colleagues as if everything was new to me as well. After this training, I spoke to one of the other participants, who earlier on seemed very reluctant to talk to me but now was more open. In his daily work, he belongs to the training and development team in the HR function and one of his tasks is to conduct similar workshops for new employees on the ethical principles of the company. I asked how he had experienced the workshops and the training, and he explained in a low voice that although he had participated in the workshops for managers that he later was trained in, he had not fully understood the purpose of these workshops until after the last HR training. It surprised me that he had not understood the purpose of the workshops, as this workshop concept is quite similar to the workshop that he is responsible for delivering on a regular basis. Moreover, it surprised me that he had neither asked the facilitator to clarify the purpose during the workshop for managers nor during the HR training. This made me wonder if the managers who attended the workshops had also not understood the purpose without mentioning anything. If this was the case, the time that 40 managers spent on these workshops might have been fruitless. This insight is rather central, as it hints towards the effectiveness (or lack thereof) of standardized training concepts when they are rolled out globally, and I might not have gained access to this insight if I had not actively taken on the role as a student. Further, I assume that if this HR employee had wanted to, he would have inquired with my colleague from the Ethics Department about the purpose of the workshop to ensure that the attending managers were not equally confused. This indicates that for some reason, he did now wish to reveal that he had not understood the purpose. However, perhaps because I had positioned myself 
as a low-ranking student rather than an authority from a corporate function, he shared this information with me. Via this student-identity, I thus gained access to knowledge that was kept from my Ethics Department colleague. At the same time, however, I also entered an ethical space that I would have not stepped foot in if my assertion of this identity had not been successful. Assuming that my local colleague's concern was not to expose himself to the superior from the Ethics Department and admit to not having understood the purpose of what 40 managers were trained in, one can probably also assume that he might not have shared this with me if he knew it would appear in a research paper. Therefore, I wonder if my positioning as a low-ranking student had been overemphasized to the extent that he had forgotten that I was indeed there to study them? As evidenced by the fact that I have included this example, I decided to share it but to do so in such a way that conceals his identity and allows only a few people to recognize where it took place. Thus, our data access is shaped by the dismissal or approval of the identities we are trying to claim and thus by the Interaction Order (Jenkins, 2008). But when we gain access to certain data precisely because of our successful attempt to take on an identity, it poses new dilemmas about what to write and what not to write about. It also forces us to consider if the identities we portray somehow shield our research purposes from our informants and hereby grant us access to information that was not intended to be shared. Similarly, just as successful identity claims might grant us access to information, moments may also occur where knowledge might be kept from us because our identity claims are rejected:

I am five months within the fieldwork. On the floor where I am located, we have a weekly meeting with general updates. By now, I have become a natural part of these meetings, and when the manager hosting the meeting asks if there is news from the Ethics Department, she looks at me 
along with my colleagues as if any of us could provide updates on behalf of the department in which, she seems to think, we all work as equals.

I feel quite at home, and instead of nervously preparing myself for the meeting as I did in the beginning, I brought a cup of coffee from the canteen to make the weekly event cozier.

After a number of updates on the upcoming summer party and news from the management team, one of the legal advisors shares a complicated legal case that they are currently working on. "Of course, this is confidential information", another colleague adds, and we all nod. In the same moment, one of the other legal advisors sitting on a chair by my side turns to me and says with a smile "So that means..." and zips an imaginary zipper over her lips, emphasizing that I especially have to pay attention to this message about confidentiality. Everybody looks at me for a second, perhaps wondering if they have said too much in front of me, but then the meeting continues with news about a new IT training module.

The zipped lips gesture may have been meant as a joke. Regardless of the intention, however, the experience taught me that as a fieldworker, although you have gained an insider identity, this identity is not fixed; rather, it can be interrupted by outsider moments at any point in time. In one instant, I was part of the group, just another staff member attending a weekly meeting; in the next moment, I was singled out as an outsider who needed an extra reminder of the confidentiality of what was discussed. Thus, in the midst of being an insider at the staff meeting, I was suddenly ascribed an identity as an outsider. As Jenkins writes, "It is not enough simply to assert an identity; that assertion must also be validated, or not, by those with whom we have dealings" (Jenkins, 2008, p. 42). My assertion of an identity as an insider was certainly not validated at that moment in time. Thus, fieldworker identities are not stable acquisitions, and we cannot assume our identities in the field to correspond to the ideal of a transition from being an outsider to becoming an insider or vice 
versa (Cf. Ergun and Erdemir, 2010). Rather, I find it useful to conceptualize the fieldworker's identities as constantly evolving and changing, and with interrupting outsider and insider moments.

\section{The Individual Order: Feeling outside in a familiar setting and getting (too) familiar}

Now, I will turn to the felt and personally experienced identities of the fieldworker and argue that this aspect of identity creation challenges the spatial notions often attached to fieldwork in familiar settings, as well as it sheds light on possible integrity risks within such research.

I am a social anthropologist, and my preference for the social sciences streams through my educational history. There are only traces of quantitative and natural sciences from lower-level biology classes in high school and 10 ECTS points in statistics from my bachelor's degree 10 years ago. As mentioned earlier, my $\mathrm{PhD}$ project takes place in a multinational biopharmaceutical company. I have been affiliated with the Danish branch of the firm where many of its research and development activities are undertaken. However, despite the short distance to work, I felt far from home when entering the company. In the following excerpt, I sit with a pharmacologist named Liza.

She has started an elaborate explanation that I am not sure where will lead, about a condition where the patient gets large polyps inside the esophagus. Her description is very vivid, and I am trying to follow her rather technical description of the condition. "And that can be dangerous, because it can create pressure on the aorta", she says and looks at me with a serious attitude. I nod, partly to recognize the severity of the condition she is describing and partly to confirm that I understand that the esophagus can be affected. Or that I thought I understood. Without giving it much thought, I ask just to confirm "So aorta is the word for the esophagus?" She stops her explanation and looks at me with disbelief in her eyes. "No...", she says and looks at me. "No, aorta is the main artery in your body...". From that comment as well as from her expression, I 
understand that the name of the main artery is rather basic knowledge that I feel I should have possessed. She looks like she agrees.

As exemplified in this excerpt, being an outsider is not only tied to spatial characteristics of home or away but also to the subject matter characteristics of the field and the expertise of the fieldworker regardless of whether the field happens to be physically located within her home country or within the familiar construct of an organization. Thus, the spatial dichotomy of home or away seems inadequate in this kind of organizational research, as the fieldworker's experienced identity also depends on the non-physical space between her educational background and the field. Returning to the Individual Order (Jenkins, 2008), it is important to note that the process of identification happens in the relation between the fieldworker and the field. Imagine, for example, that I had studied pharmacology or medical science before switching to anthropology. In that case, my notion of selfhood would likely have been that of an insider from the outset. It thus depends on both the researcher and the field as a whole and not only on the spatial or organizational affiliations of each. This means that on other occasions, as I will turn to now, in interactions with employees whose backgrounds were similar to mine, my self-ascribed identity was that of an insider.

In Denmark, I share an office with colleagues my own age, and we get along very well. In fact, we get along so well that my relation with them has been a continuous worry throughout my fieldwork. Early in the project, while I was still feeling like an outsider to the general field of study, I quickly felt and was treated like an insider among the Ethics Department. While appreciating the ease with which I have entered the department and established rapport, I am simultaneously fearful of what this might do to my data, how I write and what I write. The Ethics Department is a small corporate function, and each employee within the department has a distinct portfolio of tasks. Therefore, 
when commenting on specific activities, I am simultaneously commenting on the individual work of one or very few people. Recently, while working on another article, I was discussing with an academic colleague some of the Ethics Department's work that I had described. My colleague found that the way in which they conveyed their messages in workshops is inappropriate to the context of a biopharmaceutical company and encouraged me to criticize this. Afterwards, I found myself softening my language, concerned about whether the Ethics Department might be offended by this criticism when seeing it written up in an article (for similar reflections, see Natifu, 2016).

With this experience in mind, I realized that despite my constant worrying about it, my selfhood in the familiar field had developed to an extent where I was recognized as one of them and likewise felt like one of them, and that this had made my concerns about offending them take priority over my critical reflections about them. Thus, when operating in fields that feel familiar, we must constantly make efforts to reflect upon the implications of this familiarity on our research integrity, and ask ourselves how our fieldworker identities may be guiding our interpretations.

\section{The Individual order: Insider moments in fieldwork away}

So far, I have demonstrated that insider is not an identity we can take for granted in familiar settings. Likewise, as I will turn to next, neither is outsider an identity that we can assume to be tied to fieldwork in unfamiliar settings. During my fieldwork, I travelled to China to visit a subsidiary along with an employee from the Ethics Department. I had never been to China before, and when arriving in the airport, only able to communicate by hand gestures with the driver picking us up and not being able to read the Chinese road signs on the way into town, I felt very much away from home. This continued the next day at the office, where I kept feeling oblivious to the social codes in my interactions with my Chinese colleagues. 
I am here to attend a workshop facilitated by my colleague from the Ethics Department. 18 Chinese participants and their Danish manager are sitting in the room, waiting for the workshop to start. The facilitator has brought a ball for the participants to throw around, defining which person should speak next. The first person she throws it to makes a jittery move and fails to catch the ball. Following him, almost every person who gets the ball thrown either does not catch it, is hit by the ball or halfway catches it and then loses it again in a nervous twitching move. With every failed attempt, the Danish manager laughs and makes jokes about the incredibly low catch rate, saying that they need to put ball throwing in the development plans for next year. Everybody joins the laughter, including the flurried employees who try to be the first to catch the ball properly.

At that moment, I felt very Danish. Of course, in the group of Chinese participants, I was still very much an outsider; however, in that particular situation, where I interacted with what I recognized as Danish humor and the informal Danish management style, I felt like an insider. Thus, the spatial divide inherent in the dichotomy between home and away was again challenged, as I spent a moment as an insider, even though I was an outsider in a foreign field more than 8000 kilometers away. And such insider-moments produce new insights about the field and how we as fieldworkers understand it. For example, this particular moment made me realize that I was seeing my observations through a prism of cultural stereotypes:

Throughout the workshop, the Danish manager keeps making jokes and, I suspect, being slightly less formal than the typical Chinese CEO. Everybody seems to be enjoying themselves, and the spirits are definitely lifted by his approach. Afterwards, back in my hotel room, I spend a lot of time writing field notes about this particular aspect of the workshop and wondering how I would have seen him if I had been one of the Chinese employees. I kept thinking about why the Chinese 
participants seemed to enjoy themselves even though the Danish manager had stepped out of what I thought was the normal, Chinese management style.

Later, I realized that a somewhat stereotypical image of Chinese managers being more hierarchical had clearly informed my interpretation of the situation and made me ask such questions in the first place. Rather than being stunned by the Danish manager's informal approach, as I had assumed the Chinese participants would be, they seemed to comfortably tap into the humor just as I had done. I understood that the reason I was asking myself these questions was that I felt like an insider in that particular situation, despite my general experience of being an outsider. I assumed that if this way of being a manager was so recognizable to me, then it must have seemed foreign to the setting that seemed so foreign to me. It is difficult to determine whether the laughter emerged from a culturally engrained wish to follow the mood of the manager or it was a genuine expression of amusement. The feeling in the room suggested the latter, but regardless, it made me realize the cultural stereotypes guiding my immediate interpretation. Thus, thinking about insider and outsider moments is productive for us to consider not only our identities in the field but also our interpretations of what we experience and the preconceptions that might influence them.

\section{Conclusion}

This article has argued that to properly grasp the multiple identity processes involved in a fieldwork, we must escape the spatial and temporal conceptualization of being either an insider or an outsider. Instead, the article has argued for a relational and situational perspective on being an insider and an outsider in the field. Drawing on Jenkins' notion of social identities and the interactions inherent in the identification process, this article has sought to demonstrate that the identity of a fieldworker, regardless of where the fieldwork takes place, is defined in the relation 
between the field and the fieldworker and even in momentary interactions. Through examples from a fieldwork in a biopharmaceutical company located in the home country of the ethnographer, it has been described how this particular context proved very foreign despite the ethnographer's formal role as an employee, her familiarity with the concept of an organization as well as its geographical location. Moreover, it has demonstrated that even when inhabiting insider identities, outsider moments can emerge - and vice versa - and that these moments offer new insights about ourselves, the field and the assumptions with which we enter it.

The insights presented contribute to a growing but yet relatively unexplored field within organizational ethnography in two ways. First, by engaging the concept orders of identification, it contributes to expanding the theoretical understandings of researcher identities in familiar settings.

Second, it contributes to our methodological toolbox as organizational ethnographers by demonstrating how our social identities in the field shape the data we get access to generate. Moreover, this article has pointed towards, but not elaborated extensively on, the ethical implications of our researcher identities in the field. The importance of such questions for the quality of our research and our integrity as researchers calls for further attention within future research. Research funded by private companies makes our research purposes somewhat entangled with company agendas and our researcher selves somewhat entangled with our field sites. As private funding and ethnography in familiar settings do not seem to be diminishing in the future, I would further urge the community to perform further research and share reflections on the consequences of such entanglements on the empirical material we generate and the ethics within.

\section{Literature}

Adler, P.A. and Adler, P. (1987), “Complete Membership”, in Adler, P.A. and Adler, P. (Eds.), Membership Roles in Field Research, SAGE Publications, Inc., Thousand Oaks, pp. 68-84. 
Alvesson, M. (2003), "Methodology for close up studies: struggling with closeness and closure”, Higher Education, Vol. 46 No. 2, pp. 167-193.

Alvesson, M. (2009), “At-Home Ethnography: Struggling with Closeness and Closure”, in Ybema, S., Yanow, D., Wels, H. and Kamsteeg, F. (Eds.), Organizational Ethnography: Studying the Complexities of Everyday Life, Sage Publications, London, pp. 156-174.

Alvesson, M. (2010), "Self-doubters, strugglers, storytellers, surfers and others: Images of selfidentities in organization studies”, Human Relations, Vol 63 No. 2, pp. 193-217.

Alvesson, M., Ashcraft, K. L., \& Thomas, R. (2008), “Identity matters: Reflections on the construction of identity scholarship in organization studies", Organization Vol. 15, pp. 5-28.

Anteby, M. (2013), "PERSPECTIVE — Relaxing the Taboo on Telling Our Own Stories: Upholding Professional Distance and Personal Involvement”, Organization Science, Vol. 24 No. 4, pp. $1277-1290$.

Beech, N. (2011), "Liminality and the practices of identity reconstruction”, Human Relations, Vol. 64 No. 2, pp. 285-302.

Bell, E. (1999), “The negotiation of a working role in organizational ethnography”, International Journal of Social Research Methodology, Vol 2 No. 1, pp. 17-37.

Bolak, H.C. (1996), “Studying One's Own in the Middle East: Negotiating Gender and Self-Other Dynamics in the Field", Qualitative Sociology, Vol. 19 No. 1, pp. 107-130.

Brannen, M.Y. (2011), "Using Multiple Case Studies to Generalize Form Ethnographic Research”, in Piekkari, R. and Welch, C. (Eds.), Rethinking the Case Study in international Business and Management Research, Edward Elgar Publishing, Cheltenham, UK and Northhampton, USA, pp. $124-45$.

Brannick, T. and Coghlan, D. (2007), “In Defense of Being 'Native': The Case for Insider Academic Research", Organizational Research Methods, Vol. 10 No. 1, pp. 59-74. 
Brown, A.D. (2015), "Identities and Identity Work in Organizations", International Journal of Management Reviews, Vol. 17 No. 1, pp. 20-40.

Cui, K. 2015. "The Insider-outsider Role of a Chinese Researcher Doing Fieldwork in China: The Implications of Cultural Context.” Qualitative Social Work, Vol. 14 No. 3, pp. 356-369.

Cunliffe, A.L. and Karunanayake, G. (2013), "Working Within Hyphen- Spaces in Ethnographic Research: Implications for Research Identities and Practice", Organizational Research Methods, Vol. 16 No. 3, pp. 364-392.

Delamont, S. (2007), “Ethnography and Participant Observation”, in Seale, C., Gobo, G., Gubrium, J.F. and Silverman, D. (Eds.), Qualitative Research Practice, SAGE Publications Ltd, London, pp. 205-217.

DeWalt, M. and DeWalt, K. (2002), Participant Observation: A Guide for Fieldworkers, AltaMira Press, Oxford.

Ellis, N. \& Ybema, S. (2010), “Marketing Identities: Shifting Circles of Identification in Interorganizational Relationships”, Organization Studies, Vol 31 No. 3, pp.279-305.

Ergun, A. and Erdemir, A. (2010), "Negotiating Insider and Outsider Identities in the Field: 'Insider' in a Foreign Land; 'Outsider' in One's Own Land”, Field Methods, Vol. 22 No. 1, pp. $16-38$.

Ginkel, R. Van. (1998), “The repatriation of anthropology: some observations on endoethnography", Anthropology \& Medicine, Vol. 5 No. 3.

Goffman, E. (1990), The Presentation of Self in Everyday Life, Penguin Books, London.

Gurney, J.N. (1985), "Not One of the Guys: The Female Researcher in a Male-Dominated Setting", Qualitative Sociology, Vol. 8 No. 1, pp. 42-62.

Halstead, N. (2007), "Ethnographic encounters. Positionings within and outside the insider frame", Social Anthropology, Vol. 9 No. 3, pp. 307-321. 
Jenkins, R. (2008), Social Identity, 3. ed., Routledge, London.

Järventie-Thesleff, R., Logemann, M., Piekkari, R. and Tienari, J. (2016), "Roles and identity work in 'at-home' ethnography”, Journal of Organizational Ethnography, Vol. 5 No. 3, pp. 235257.

Kaptein, M. (2004), “Business Codes of Multinational Firms: What Do They Say?”, Journal of Business Ethics, Vol. 50 No. 1, pp. 13-31.

Kaptein, M. (2015), “The Effectiveness of Ethics Programs: The Role of Scope, Composition, and Sequence", Journal of Business Ethics, Vol. 132 No. 2, pp. 415-431.

Karra, N. and Phillips, N. (2008), "Researching 'Back Home': International Management Research as Autoethnography”, Organizational Research Methods, Vol. 11 No. 3, pp. 541-561.

Kusow, A.M. (2003), "Beyond Indigenous Authenticity: Reflections on the Insider/Outsider Debate in Immigration Research", Symbolic Interaction, Vol. 26 No. 4, pp. 591-599.

Ma, Z., Liang, D., Yu, K.H., \& Lee, Y. (2012), ”Most cited business ethics publications: Mapping the intellectual structure of business ethics studies in 2001-2008", Business Ethics: A European Review, Vol. 21 No. 3, pp. 286-297.

Marcus, G. (1995), "Ethnography in/of the world-system. The emergence of multi-sited ethnography", Annual Review of Anthropology, Vol. 24, pp. 95-117.

Marschan-Piekkari, R., Welch, C., Penttinen, H. and Tahvanainen, M. (2004), "Interviewing in the Multinational Corporation: Challenges of the Organizational Context”, in Welch, C. and Marschan-Piekkari, R. (Eds.), Handbook of Qualitative Research Methods for International Business, Edward Elgar, Cheltenham, UK and Northampton, pp. 244-263.

Merton, R.K. (1972), "Insiders and Outsiders: A Chapter in the Sociology of Knowledge”, American Journal of Sociology, Vol. 78 No. 1, pp. 9-47.

Van Maanen, J. (1995), “An End to Innocence: The Ethnography of Ethnography”, in Van Maanen, 
J. (Ed.), Representation in Ethnography, SAGE Publications, Inc., Thousand Oaks, pp. 1-35.

Narayan, K. (1993), “How Native Is a 'Native’ Anthropologist?”, American Anthropologist, Vol. 95 No. 3, pp. 671-686.

Natifu, B. (2016), “Multiple levels of 'knowing and being known', their affiliated capital, benefits and challenges", Journal of Organizational Ethnography, Vol. 5 No. 3, pp. 219-234.

Pant, A. and Ramachandran, J. (2017), "Navigating identity duality in multinational subsidiaries: A paradox lens on identity claims at Hindustan Unilever 1959-2015”, Journal of International Business Studies, Vol. 48, pp. 664-692.

Roth, K. and Kostova, T. (2003), “The Use of the Multinational Corporation as a Research Context", Journal of Management, Vol. 29 No. 6, pp. 883-902.

Smets, M., Burke, G., Jarzabkowski, P. and Spee, P. (2014), "Charting new territory for organizational ethnography: Insights from a team-based video ethnography”, Journal of Organizational Ethnography, Vol. 3 No. 1, pp. 10-26.

Tseng, H., Duan, C., Tung, H. and Kung, H. (2010), ’Moden business ethics research: Concepts, Theories, and Relationships", Journal of Business Ethics, Vol. 91 No 4, pp. 587-597.

Weaver, G. R. (1993). “Corporate Codes of Ethics: Purpose, Process and Content Issues”, Business \& Society, Vol 32 No. 1, pp. 44-58.

Winkler, I. (2012), "Moments of identity formation and reformation: a day in the working life of an academic", Journal of Organizational Ethnography, Vol. 2 No. 1, pp. 191-209.

Ybema, S. and Kamsteeg, F. (2009), "Making the Familiar Strange: A Case for Disengaged Organizational Ethnography”, in Ybema, S., Yanow, D., Wels, H. and Kamsteeg, F. (Eds.), Organizational Ethnography: Studying the Complexities of Everyday Life, SAGE Publications Ltd, London, pp. 101-119. 
